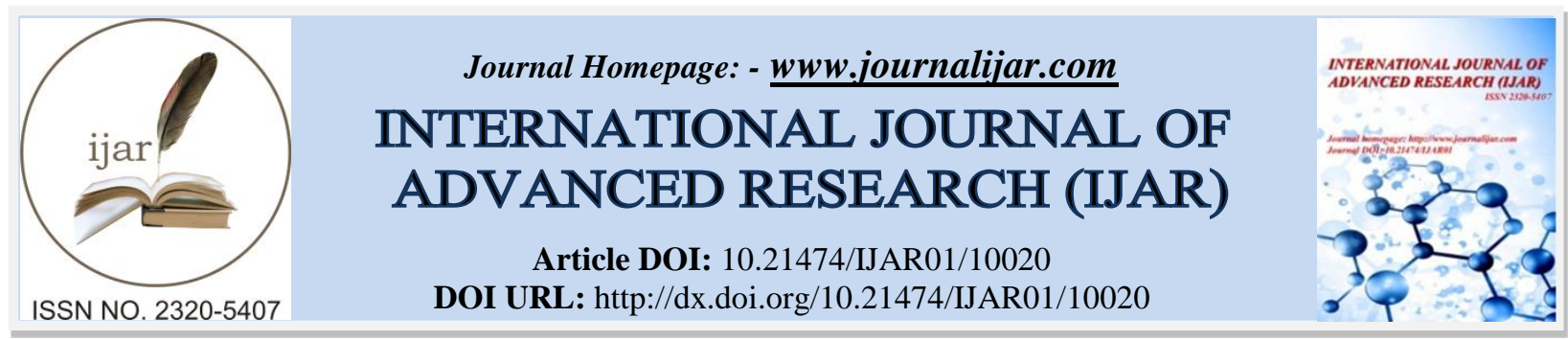

RESEARCH ARTICLE

\title{
PRACTICALITY OF INTEGRATED NATURAL SCIENCE STUDENT BOOKS WITH THE THEME SENSES OF SIGHT AND OPTICAL DEVICES USING CONNECTED MODEL FOR INTEGRATED 21ST CENTURY LEARNING.
}

Firda Weri $^{1}$, Ayu Melati ${ }^{1}$, Ratnawulan ${ }^{2}$ and Syafriani ${ }^{2}$.

1. Student of Magister Degree Program of Physics Education, Universitas Negeri Padang Jl. Prof. Dr. Hamka Air Tawar Barat Padang-25131, Indonesia.

2. Lecturer of Master Degree Program of Physics Education, Universitas Negeri Padang, Jl. Prof Hamka Air Tawar Barat Padang -25131, Indonesia.

\section{Manuscript Info}

\section{Manuscript History}

Received: 08 September 2019

Final Accepted: 10 October 2019

Published: November 2019

Key words:-

Practicality, Integrated Natural Science, Student Books, 21st Century Learning.

\begin{abstract}
Integrated natural science student books should contain learning that is relevant to the learning characteristics of the 21 st century that aim to develop talent, potential learners to character, interests, literacy and competent. To make use of this integrated natural science student books, then need to be practiced. The purpose of the practicality is to know the practiced integrated natural science student books with the theme senses of sight and optical devices using connected model for integrated 21 st century learning to use likert scale with 2 practitioners is two teacher from Junior High School 13 Kerinci, Jambi and 21 practitioners from the students. The questionnaire used the data of collection method. The result is composed of fill in teaching materials, offerings in teaching materials and the benefits of teaching materials with practical categories. While practitioners composed from the students same with two teachers. Conclusion, overall the integrated natural science student books with the theme senses of sight and optical devices using connected model for integrated 21 st century learning be avowed practical and it can to be use in school.
\end{abstract}

Copy Right, IJAR, 2019,. All rights reserved.

\section{Introduction:-}

Education today has entered the 21 st century education which has opened the widest opportunity for global competition. 21st century education is carried out through 21 st century learning. The most important thing in learning 21st century is to encourage students to have the knowledge base and deep understanding becoming lifelong learners (Afandi, 2016). The goal of learning the 21st century is to encourage learners to master the skills appropriate to the 21 st century. 21 st century learning emphasizes on four competencies, namely communication, collaboration, critical thinking, and creativity (Firda, 2019). The Indonesian government as the guarantor of implementation of education has made efforts to improve the quality of education in Indonesia in accordance with the demands of the 21st century. One of the efforts is by learning resources. Learning resources is a major factor that can support to optimize skills possessed by students one of them is a student book. Student book who used in school are still not optimal manufacture and use, because is the skill of the 21 st century $4 \mathrm{C}$. There fore the learning objectives will be difficult to achieve integrated science (Prastowo, 2013).

Corresponding Author:-Ratnawulan.

Address:-Student of Magister Degree Program of Physics Education, Universitas Negeri Padang Jl. Prof. Dr. Hamka Air Tawar Barat Padang-25131, Indonesia. 
Student book is a book that contains a description of the subject matter or the particular field of study, systematically arranged and have been selected based on specific objectives, learning orientation, and development of learners to be assimilated. Student book or commonly called text book is one resource that serves as a means of supporting learning activities (Kurniawan \& Luthfiyah, 2013). Each chapter of the book comes with a map concept students, introduction, part of students' activities, both experimental and non-experimental or discussion, practice questions, a summary of the evaluation, and tasks for students (Gusnedi, Ratanawulan \& Triana, 2018). There textbooks students can help teachers to deliver learning materials so that learning objectives can be achieved, and to face the challenges of the 21 st century textbooks should integrate the skills required in the 21 st century learning (Firda, 2019).

Students used books will be eligible to used if it is practical to use. Before the practitioner in the student book that would be used, carried out prior validation of the isntrument of instrument practicalities of a decent instrument used validation. Sheets practicalities of integrated science student book, used to study the response of teachers and learners about the practicalities of the product developed. The practicalities instrument in the form of a questionnaire completed by teachers and learners who have been carrying out learning activities using integrated science student book.

The contents of the book are a translation or a description of the student's learning materials specified subjects in the curriculum (Sitepu, 2015). Integrated learning based on themes and connect a range of subjects to give the students experience a meaningful (Amini, 2017), and understanding learners become more whole (Ashokan, 2014). Material in Junior High School for natural science subjects based on the theme that connectes physics, biology and chemistry concept as a whole (Sani, 2014).

The analysis of learning difficulties, it is known that students still have difficulty understanding the material contained in student books, student books used in learning are still less interesting and students are still having difficulty in solving science problems. While the integration of 21st century learning in integrated natural science student's text books are not yet developed also, this is evidenced by the results of the data to the analysis of integrated 21st century learning (Firda, 2019). Therefore, it takes the book integrated science to improve the competence and professionalism of teachers to meet the demands of the development of skills/ character of 21st century (Rahima, 2019). Reviews these characteristics are in accordance with 21 st century learning characteristics. Therefore, developing student learning resources/ book in accordance with the characterictics of students mandated by the curriculum can be done (Toni, 2019).

IPA is one branch of science that discusses the phenomenon of natural phenomena systematically. In general, IPA includes three basic sciences, including: biology, physics, and chemistry (Prastowo, 2013). Natural science is defined as systematic knowledge and constituted by linking the material nature phenomena and based on observations and inductions (Chang, 2002). IPA study at junior high school / MTs applies integrated science learning based on Permendikbud No. 68 Year 2013 state that science lessons of SMP/MTs are developed as integrative subjects of applied-oriented science, the developmentof thinking ability, learning ability, curiosity, caring attitude, and responsibility to the natural environment (Febrilla, Ratnawulan \& Usmeldi, 2019).

At present, science learning at junior hight schools has undergone several changes, including the scope of science learning that was previously separated based on each discipline has now been developed into a discipline that can later broaden students insights into integrated science. Throught integrated science learning students can gain direct experience, so they can add strenght to receive, save, and apply the concepts they have learned. Students are trained to be able to discover for themselves a variety of concepts that are studied thoroughly (holistically), meaningful, authentic and active. Integrated learning is learning with a specific theme for hooking interdisciplinary by hooking into everyday life. In learning science can be done with a variety of models of integration (Fogarty, 1991). A number of integrated learning models is suitable for learning science developed in the level of education in Indonesia. The three models in question is a model of connectedness (connected), the model cobwebs (webbed), and models of integration.

One integrated model that can be applied to science learning that can help students to connec ideas about the concepts of integration between physics, biology, and chemistry is the connected model. Connected is a model of curriculum integration between fields of study, which obviously connects one topic, skills, and concepts in the subject sub-topics associated with topic, skills, and concepts in the sub-principal other topics in the fields of study, the primary key connected models is the presence of a conscious effort to connect the field of study in the 
disciplines (Fogarty, 1991). Integrated learning with type connected model actually organizes or integrates a concept, skill or capability that is developed in a subject or sub-topic that is discusses with a concept, skill or ability in another subject or sub-subject in one field of study. Linkages can be held spontaneously or planned in advance, so learning becomes more meaningful and effective. In other words, that integrated type connected learning is learning done by linking one subject to the next. Linking one concept to another, linking one skill with another. Connected type integrated learning is a model of interdisciplinary integration in which this type links two or more cognate fields of study. The main concern in the application of this type of learning is carefulness in identifying and establishing indicators that will be mapped on each subject to be integrated. In the teaching and learning process, connected type are used to connect several materials.

The reality in the field, based on assessment of 21st century skills of students in junior high school 13 in the area Kerinci, Jambi, Indonesia in the academic year 2018/2019 there are any discrepancies with the expectation that happened at school. 21st century skills of learners are still low. The results of obeservations conducted at junior high school 13 in the area kerinci, Jambi, Indonesia, is currently science learning that is expected by the 2013 curriculum is integrated science learning has not run maximally. Most teachers have not yet practiced an intagrated IPA learning model and have difficulty in designing integrated science learning in learning in terms of physics, biology, and chemistry, in addition there is no teaching material such as textbooks integrated natural sciences that integrated and most likely the book has not met the demands of 21 st century learning. So thet impact on the learning outcomes of learners who are still difficult to connec ideas about the concepts of integration between physics, biology, and chemistry. Implementation of integrated science teaching have not been implemented to the maximum, this is due to importance of books students in learning is not a serious concern in learning. Guide students into a learning resource for students so that they can guide the learners in understanding science concepts. Student book has the advantage that there is a lot of information on knowledge, attitudes, and skills to the achievement of competence of learners (Prastowo, 2013).

Therefore, to solve such learning problems need for the practicalities of student books is easy to understand, interesting and efficient. Through preliminary research books used in teaching students who have not been in line with expectations. Books of students who are expected to have a language that is simple and easy to understand, according to the scientific and include skills of the 21 st century and in conformity with the guidance of national education today is to improve the skills of the 21 st century in order to respond to global challenges.

Based on the existing problems, the aim of this study was to test the practicality of integrated natural science student book with the theme senses of sight and optical devices using connected model for integrated 21 st century learning.

\section{Methods:-}

The research is a descriptive research. Descriptive study aimed to describe the phenomena or events (Gay \& Peter, 1996). Data collected in the form of figures are interpreted in the form of description. Design of the book was given to practitioners in practicality test. Practical is a process to assess whether the design of the product is practical or not to use.

Practicalities closely with the ease and learners progress made in the use of integrated science student book. Gluepracticality two test use was twofold: practicality test sheet according to teachers and practicality test sheet according to learners. The following indicators practicality of the product to be used in the development of student book with the theme senses of sight and optical devices using connected model for integrated 21 st century learning in Table 1.

Table 1:-Indicators Practicality of The Product

\begin{tabular}{|c|c|c|}
\hline No & Indicator & Description \\
\hline 1 & Easy to Understand & $\begin{array}{r}\text { Easy to understand in term of material, concept maps, sample } \\
\text { questions, exercises, activity sheets, and evaluations. }\end{array}$ \\
\hline 2 & Attractive & $\begin{array}{r}\text { Interesting in terms of color composition, themes related to the } \\
\text { material, and full of information }\end{array}$ \\
\hline 3 & Efficient & $\begin{array}{r}\text { Efficient in terms of time understanding student books and can be used } \\
\text { without a teacher or friend }\end{array}$ \\
\hline
\end{tabular}


Practicalities questionnaire data analysis products using the Likert Scale. The practicalities of analysis steps performed are as follows:

1. Give a score for each item answer strongly agree (4), agree (3), not agree (2), and strongly disagree (1).

2. Add up the total score for each practitioner for all indicators,

3. Giving the practicalities value by using the formula:

Information:

$$
P=\frac{\mathrm{f}}{\mathrm{N}} \times 100 \%
$$

$\mathrm{P}=$ The end

$\mathrm{f}=$ Earned score

$\mathrm{N}=$ Maximum score

Category practicality can be seen in Table 2 .

Table 2:-Category Practicality

\begin{tabular}{|l|l|l|}
\hline No & Value & Criteria \\
\hline 1 & $81 \%<\mathrm{x} \leq 100 \%$ & Very Practical \\
\hline 2 & $61 \%<\mathrm{x} \leq 80 \%$ & Practical \\
\hline 3 & $41 \%<\mathrm{x} \leq 60 \%$ & Quite Practical \\
\hline 4 & $21 \%<\mathrm{x} \leq 40 \%$ & Less Practical \\
\hline 5 & $0 \%<\mathrm{x} \leq 20 \%$ & Not Practical \\
\hline
\end{tabular}

Source: Modified from Ridwan, 2012

Based on Table 2 it can be seen that the students developed practical book when it has a score at the interval 61-80.

\section{Results and Discussion:-}

The test is done in class VII Junior High School 13 Kerinci. Implementation of the trials held four meetings. The material on which the material IPA Objects and Observations meeting four times a meeting where the number of hours of teaching science in one week is five hours of lessons. After all the meetings completed, student were asked to complete a questionnaire practicality student book. The same thing is done by the teacher. The data practicality student book is described as follows.

Testing practicality integrated science student book involves two teachers and 21 students of class one Junior High School 13 Kerinci. There are five steps in this phase: 1) objective and user guide that axplains to teachers and students; 2) Teachers were asked to test the practicality students book who want to use; 3) After the book practicality test students by teachers, the next book in the update by researchers in accordance with the advice of the teacher; 4) After the integrated science students book are introduce, students were asked to collaborate in their discussion group; 5) In the group - a group of students learning with discussion method, using the integrated science students book and facilitated by teachers; 6) Teachers observe students to see their difficulties; and 7) The students were asked to complete a questionnaire practicality.

Teacher questionnaire responses provided to determine the response of teachers to guide students who have already been developed. Teacher questionnaire responses compiled from several indicators that are easy to understand, interesting, and efficient. This questionnaire is filled by two science taechers. Analysis of data obtained from the questionnaire responses respectively practicalities of teachers to guide students, in quick results practicalities sheet teacher response can be seen in Table 3 .

Table 3:-Results Analysis Questionnaire Response Practicalities of Educators

\begin{tabular}{|l|l|l|}
\hline No & Indicator & Value $(\%)$ \\
\hline 1 & Easy to understand & 87,50 \\
\hline 2 & Interesting & 92,50 \\
\hline 3 & Efficiently & 90,62 \\
\hline Average & 90,20 \\
\hline Category & Very Practical \\
\hline
\end{tabular}


Based on Table 3 shown that the assessment of teachers to guide integrated natural science student book with the theme senses of sight and optical devices using connected model for integrated 21st century learning that have been developed has a very practical category with an average value $90,20 \%$. The lowest value is in the category easy to understand. Respondents teachers assess students book were developed that can assist teachers assess students book were developed that can assist teachers in delivering learning materials and can be helped by the material that is integrated. For more detail can be seen on the following chart.

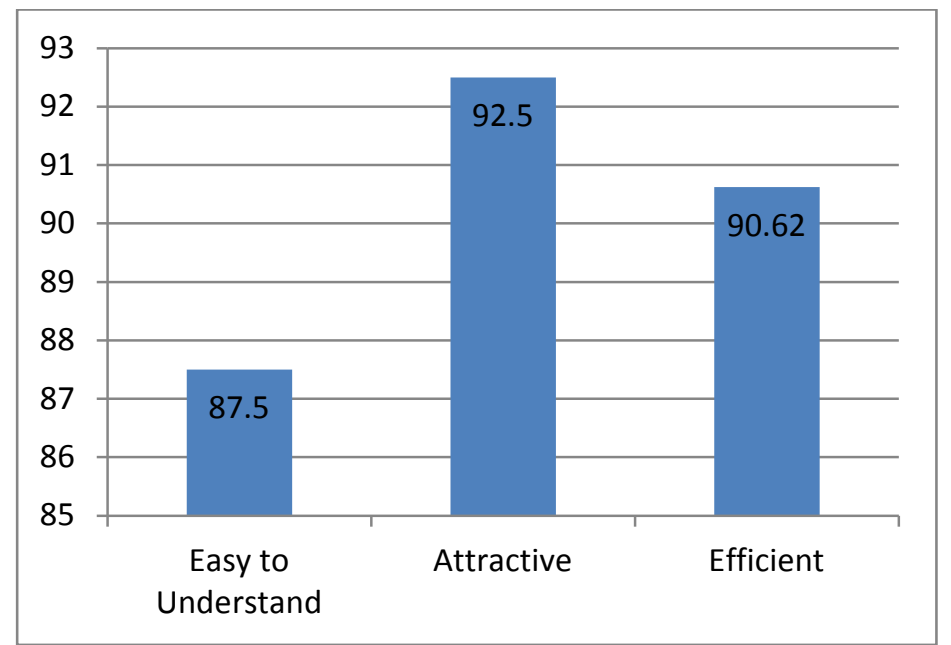

Fig 1:- The average value of Practicality by The Teacher

Practicality test student book from the response of learners using the questionnaire responses of learners. Questionnaire practicality of the book consists of three indicators with 15 statements. Those indicators include: 1) easy to understand in terms of material, mind maps, sample questions, exercises, activity sheets, and evaluation, 2) attactive interms of color composition, themes concerning the matter, and full of information, 3) efficient in terms of time to understand the students book and can be used without a teacher or friend. In addition, testing the practicality of students book use a different questionnaire. Initially, the indicators for practicality test was developed based on three aspects: easy to understand, interesting and efficient. The particsciencents were asked to respond by using a 4point likert scale, from strongly disagree to strongly agree. At the end of the questionnaire practicality, an openended question was added to ask for a recommendation to revise the integrated science students book. The results of the analysis of the practicality described in the next table.

Table 4:-Result of The Practicalities Response Assessment of Students

\begin{tabular}{|l|l|l|}
\hline No & Indicator & Value (\%) \\
\hline 1 & Easy to understand & 82,93 \\
\hline 2 & Interesting & 84,78 \\
\hline 3 & Efficiently & 82,73 \\
\hline Average & 83,48 \\
\hline Category & Very Practical \\
\hline
\end{tabular}

For more details can be seen on the following chart. 


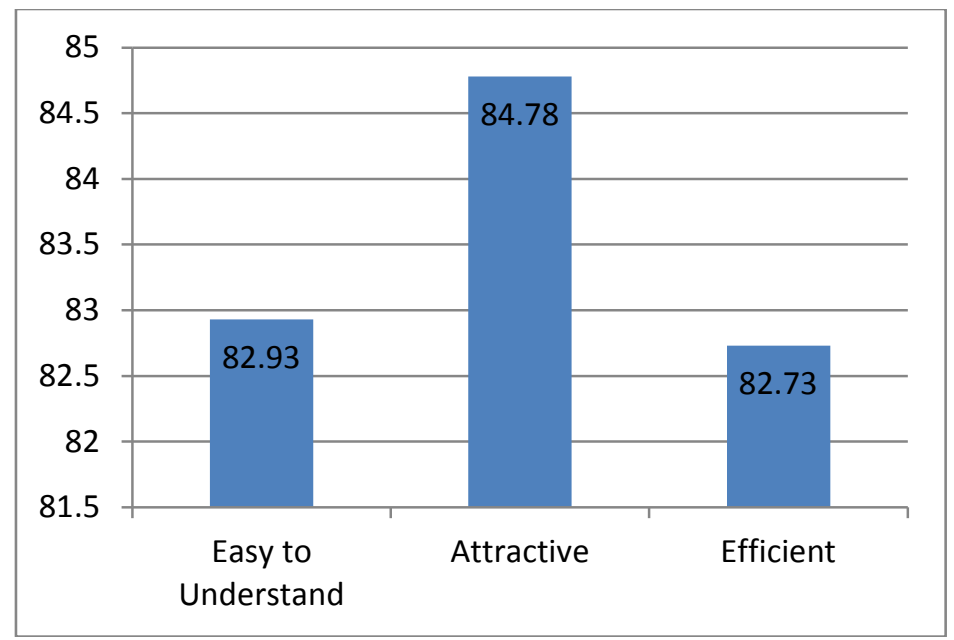

Fig 2:- The average value of Practicality by The Students.

Practicability test students book made by teachers and learners. Acquistion of the practicalities of data obtained from the practicalities questionnaire filled out by students and teachers. Practicality visits fom students book is easy to understand, attract, and inefficiency of students book. The level of practicality views of whether the teacher (and other experts) consider that the material is easy and can be used by teachers and learners (Rochmad, 2012). Test practicalities done through three phases: evaluation of one to one, small group evaluation and field testing.

The result of the evaluation stage one by one and small groups that are in the practical category. The product is practical if the measurement of the instrument is at a value $60 \%<\mathrm{x} \leq 80 \%$. This shows that the students book have been easily understood and appealing, but inefficient the student book because the time is quite limited in its use (Ridwan, 2012).

The result of the field test phase in the category very practical. The product is pratical if the measurement of the instrument is at a value $80 \%<x \leq 100 \%$. Field tests conducted by teachers and learners. This indicates that material in the students book has been easily understood, interesting, and efficient use of time for both teachers and learners. Students book can be used to facilitate the teachers of learners in the learning process, which means very practical in carrying out the study.

From the results of the field tests easily understood aspect, attractive, and efficient conducted in Junior High School 13 Kerinci can concluded integrated natural science student book with the theme senses of sight and optical devices using connected model for integrated 21 st century learning is very practical.

\section{Conclusion:-}

Based on the result of research and discussion shows the practicality of testing student books go well, the practicalities do have fulfilled materials development pattern in accordance with the characteristics of good teaching materials. It also means that the student books has fulfilled a practical indicator that includes easy understanding, interesting and efficient. Thus, the student books can be practically used in integrated science teaching in schools.

\section{References:-}

1. Afandi, Sincere, J., \& Rachmi, A. 2016. Implementation of Digital-Age Literacy in the 21st Century Education in Indonesia. Seminar Nasional Pendidikan Sains.

2. Amini R. 2017. The Development of Integrated Learning Based Student's Book to Improve Elementary School Student,s Competence . Unnes Science Education J. 6 (2): 1576-1582.

3. Ashokan V. 2014. Thematic Approach for Effective Communication in ECCE Int. J. Of Education and Physchological Research (IJEPR) 33.

4. Chang. W. 2002. Interactive Teaching Approach in Year One University Physics in Taiwan: Implementation and Evaluation. Taiwan: Implementation and Evaluation (accessed: 27 juni 2019). 
5. Febrilla, Ratnawulan, and Usmeldi. 2019. Validity of Integrated Natural Science Teacher's Book Eith Immersed Type That Contain Character on Subject of Bio-electrical Energy By Using Science Process Skills Approach. IOP Conf. Series: Journal of Physics 1185(2019)012076.

6. Fogarty, R. 1991. Ten ways to integrated curiculum. Palatine Illinois: IRI / SkylightPublishing, Inc. (Accessed 03 September 2019)

7. Gay L R and Peter A. 1996. Educational Research Competencies for Analysis and Application. New Jersey: Prentice-Hall.

8. Gusnedi, Ratnawulan, and L Triana. 2018. Application of the Student Book Based On Integrated Learning Model Of Networked Type With Heart Electrical Activity Theme For Junior High School. IOP Conf. Series: Materials Science and Engineering 335 (2018) 012132.

9. Kurniawan, AD., And Luthfiyah, N. 2013. Pengembangan Buku Siswa Untuk Meningkatkan Proses dan Hasil Belajar Kompetensi Dasar Cornflake Cookies Pada Siswa Tunagrahita SMA-LB Negeri Gedangan Sidoarjo. Ejournal boga Volume 2, No. 1, Hal. 6-17.

10. Prastowo A. 2013. Pengembangan Bahan Ajar Tematik. Yogyakarta: Diva Press.

11. Rahmiwati, S., Ratnawulan, and Yohandri. 2018. The Implementation of Integrated Natural Science Textbook of Junior High School Be Charged on Character-based Shared Models to Improve the Competence of Learners' Knowledge. IOP Conf. Series: Materials Science and Engineering 335 (2018) 012076.

12. Ridwan. (2012). Metode dan Teknik Menyusun Proposal Penelitian. Bandung: Alfabeta.

13. Rochmad. 2012. Pengembangan Model Pembelajaran: Mengaju Pada Plomp Jurnal). Semarang: UNNES.

14. Sarmi, Rahima Syabrina. 2019. Learning Media Analysis in The Development of Integreted Science Teacher Book with Theme The Energy in The Life Using Type Integrated of 21st Century Learning. IOP Conf. Series: Journal of Physics: Conf. Series 1185 (2019) 012080.

15. Sitepu. 2015. Penulisan Buku Teks Pelajaran. Jakarta: Rosda Karya.

16. Supriadi, Toni. 2019. Identification Characteristics of Student in The Development of Integrated Natural Science Student Books Integrated 21th Century Learning: A Case Study in SMP N 3 Talamau West Pasaman. IOP Conf. Series: Journal of Physics: Conf. Series 1185 (2019) 012117

17. Weri, Firda. 2019. Analysis of Student Textbook in The Development of Integrated Natural Science Student Book With The Theme Senses of Sight and Optical Devices Using Connected Model for Integrated 21st Century Learning. IOP Conf. Series: Journal of Physics 1185(2019)012113. 